\title{
IN VITRO TESTING OF A POLYLACTIC POLYMER SYNTHESIZED FROM WHEY
}

\author{
ALEXANDRA DREANCĂ ${ }^{a}$, RADU A POPESCU ${ }^{a, b}$, AMALIA NEAGU $^{a}$, \\ GEORGE ENACRACHI ${ }^{a}$, IULIA CIMPOEȘ ${ }^{a}$, NICODIM FIȚ ${ }^{\mathrm{a}}$, \\ MARIOARA MOLDOVAN ${ }^{c *}$, LAURA SILAGHI DUMITRESCU \\ ANCA JURJ $^{\mathrm{d}}$, IOANA BERINDAN-NEAGOE ${ }^{\mathrm{d}}$, IOAN MARCUS ${ }^{\mathrm{a}}$
}

\begin{abstract}
The main purpose of this research is in vitro biocompatibility testing of a polylactic acid polymer (PLA) synthesized by the condensation of lactic acid separated from whey (Zonar). The experimental PLA obtained was characterized by: Scanning Electron Microscopy which pointed a homogeneous microstructure of the polymer without a separation phase and differential scanning calorimetry (DSC) analysis which indicated a melting point of $174^{\circ} \mathrm{C}$ of the biomaterial. The cytotoxicity test for experimentally obtained polymer was performed according to ISO $10993-12^{3}$. Six solutions of different concentrations were prepared $(30 \mathrm{mg} / \mathrm{ml}, 20 \mathrm{mg} / \mathrm{ml}, 10 \mathrm{mg} / \mathrm{ml}, 5$ $\mathrm{mg} / \mathrm{ml}, 2.5 \mathrm{mg} / \mathrm{ml}$ and $1.25 \mathrm{mg} / \mathrm{ml}$ ) and were tested on a fibroblast culture at 48 hours using MTT cell viability and proliferation assay. At $48 \mathrm{~h}$ the obtained polylactic polymer showed good compatibility with an IC 50 of $64.82 \mathrm{mg} / \mathrm{ml}$. The results showed that the cytotoxicity level can be influenced by the period of time in which the extract acts on the cell culture.
\end{abstract}

Keywords: whey, polylactic acid, cytotoxicity, biocompatibility, eco-friendly

\section{INTRODUCTION}

Whey is a waste product of dairy industry, with numerous valuable ingredients such as proteins, minerals, vitamins and lactose. Global dairy production is estimated at 160 million tones liters / year, of which about $50 \%$

\footnotetext{
a University of Agricultural Sciencies and Veterinary Medicine, Faculty of Veterinary Medicine, No.3-5 Calea Manastur str.,400372 Cluj-Napoca, Romania

${ }^{b}$ Babeș-Bolyai University, Interdisciplinary Research Institute on Bio-Nano-Sciences, Nanostructured Materials and Bio-Nano-Interfaces Center, 400271, Cluj-Napoca, Romania

${ }^{c}$ Babeş-Bolyai University, Raluca Ripan Chemistry Research Institute, Cluj-Napoca, Romania

d Iuliu Hațieganu University of Medicine and Pharmacy, Faculty of Medicine, Institute of Molecular Biology, Cluj-Napoca, Romania

*Corresponding author: mmoldovan2004@yahoo.com
} 
is produced in EU Member States [1]. In Romania, the annual whey production was estimated to 300 milion liters in 2013 [2]. Zonar [3] is a sweet whey beverage with an ecological and medicinal purpose. Beyond its direct applications in the food and pharmacological fields, lactose is a valuable raw material for processing by fermentation or chemical transformation [3]. Due to its high content in lactose $(4.82 \mathrm{~g} / 100 \mathrm{ml})$, whey (Zonar) processing takes a biotechnological innovative direction of lactic acid production [4]. Through chemical synthesis, the production of lactic acid is developed using waste products from food industry and agricultural production [5]. Among these potential sources are: starch materials (potatoes, wheat, corn, etc.), waste products (whey, molasses) and cellulose products (rice, corn straw, wheat, etc.). Lactic acid is used in the production of polylactic polymers $[5,6]$.

Polylactic acid (PLA) and its copolymers have a wide range of applications in fields such as: biomedicine, pharmacy, food industry, packaging [7]. Polylactic acid is an aliphatic polyester derived from exclusively renewable sources [8]. It is an ideal material, suited for many applications, such as: packaging, paper coating, fibers, films, molded articles, etc. Polylactic polymers, due to their exceptional properties are the most used medical devices in various fields: orthopedics, delivery systems, tissue regeneration. PLA may be implemented in tissue engineering applications such as: scaffolds, autografted skin, wound covers, stents, anastomose systems [9. Polymers based on lactic and glycolic acids could be a great choice to substitute traditional metallic or ceramic materials [10].

The synthesis of PLA may be achieved by three polymerization routes: condensation (generating low molecular weight PLA), ring opening polymerization and chemical catalysis respectively (which are producing high molecular weight PLA) $[11,12]$, completed by numerous studies reporting progresses in the methods development as well as mechanical, physical and chemical properties of the polymer. It is known that the mechanical and crystallization behavior of PLA is dependent on the molecular weight and the stereo chemical makeup of the backbone [13].

Polylactic acid production offers advantages such as renewable resources, biocompatibility, processability and energy saving [7, 9].

Biocompatibility is the most attractive property of PLA with respect to the biomedical field [14]. PLA in vivo is not toxic, nor has any carcinogenic effects in tissues [10]. Polylactic polymer degradation occurs by hydrolysis in living organisms and by thermal activation in nature [7]. The degradation products are water and dioxide carbon, which are non-toxic products further metabolized by cells biocompatibility and biodegradability offer a broad spectrum of applications in many different areas including regenerative medicine. 
The aim of this research was the in vitro biocompatibility testing of a polylactic polymer synthesized from whey (Zonar) in comparison with a commercial PLA. The study also described physical properties of the experimental sample by scanning electron microscopy and calorimetric analysis. Additionally, the sterilization capacity of UV light on solid commercial and experimental polymer was determined.

\section{RESULTS AND DISCUSSION}

Some of the physico-chemical properties of polymeric biomaterials, which may have an effect on their biocompatibility include: chemical properties, hydrophilicity/hydrophobicity, molecular weight, solubility, water absorption, shape and structure, degradation and erosion mechanism.

\section{Scanning electron microscopy}

SEM images have revealed that the synthesis polymer displayed good morphology. A homogeneous microstructure of the polymer was noticed, without a separation phase (Fig. 1), unlike a previous study where it was stated that neat PLA undergoes a brittle fracture and only a combination between PLA and another polymer was capable to ensure a smooth and homogenous microstructure [15]. Another study demonstrated that pure PLA scaffolds had a honeycomb surface with a microporous structure. It also showed that the polymers surface structure influences the biologic activity (adhesion, migration and proliferation) of cultured cells [16]. Additionally, other studies stated that micro particles or nanoparticles made of low molecular PLA had smooth and non-porous surface [17]. Microspheres of PLA or other PLA blends presented no signs of collapse [17]. It was found that the polymer type and molecular weight did not affect the morphology of the micro or nanoparticles [18], suggesting that our material is a good candidate for future composite biomaterial synthesis.

\section{Thermal analysis investigation}

Auras et al, 2004 stated that the crystallization formation of PLA depends on thermal history and stereochemistry [19]. Studies showed that polymers melting temperature increases directly proportional with its PLLA content. Our synthesis polymer has PLLA stereochemistry. The DSC analysis revealed a melting point of $168^{\circ} \mathrm{C}$ and commercial PLLA of $174^{\circ} \mathrm{C}$ (Fig. 2). 


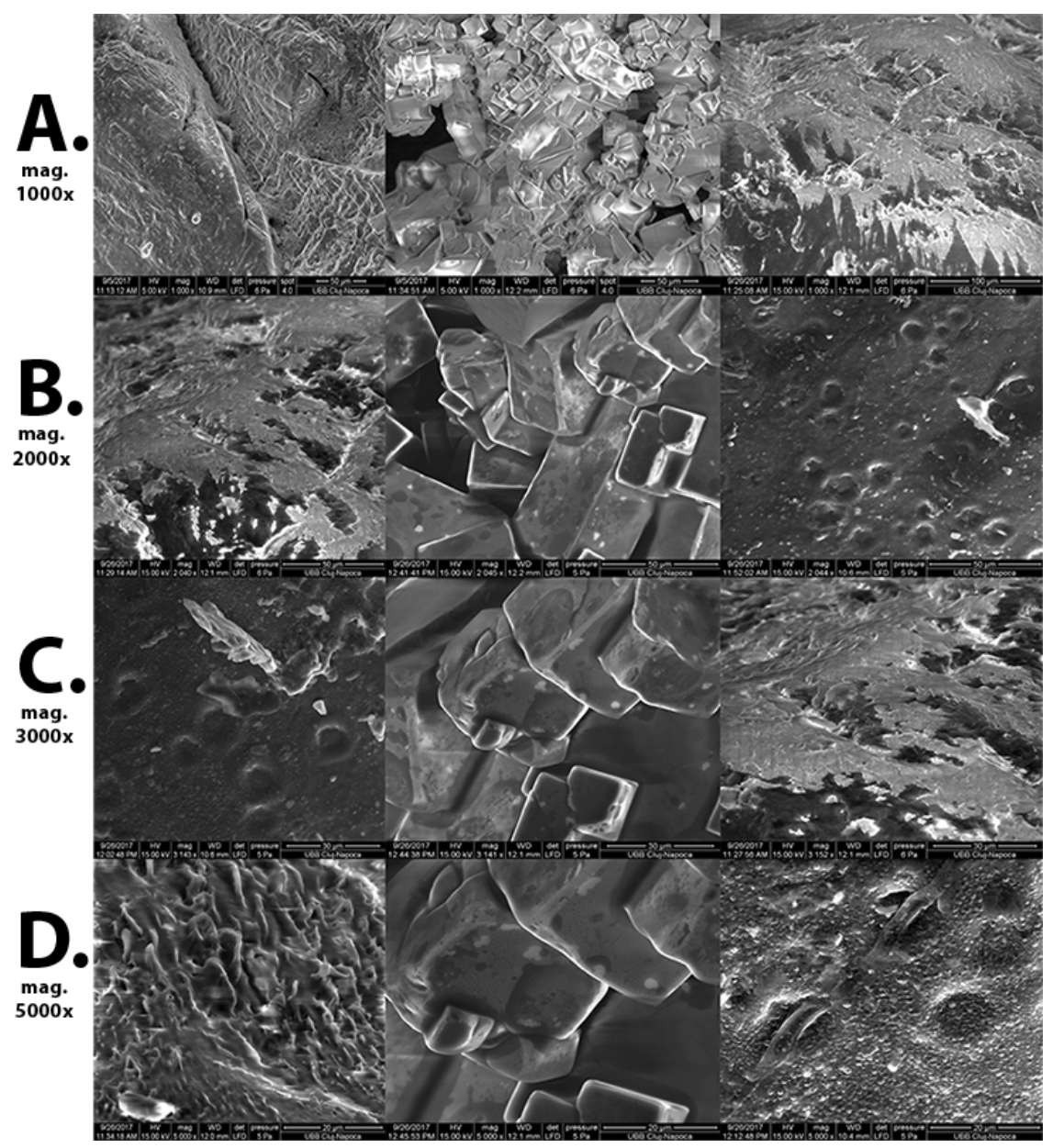

Figure 1. SEM micrograph of the polylactic polymer after chemical engineering process.

The thermal behavior, specifically the melting point of the newly synthesized PLA was similar with results from previous studies, where the melting temperatures of PLA obtained through polycondensation were between $173-178^{\circ} \mathrm{C}[9]$. Additionally, authors stated that PLLA thermal and mechanical properties were higher than other stereoisomeric rations [20]. Another thermal investigation showed a melting point of $127^{\circ} \mathrm{C}$ for low molecular PLA [21]. Palacio et al, 2011 stated that the thermal behavior of low molecular PLA and high molecular PLA are similar, but low molecular PLA starts to decompose at lower temperature than the high molecular one [21]. 
In a previous study the DSC analysis showed that neat PLA had a melting temperature of $151.10^{\circ} \mathrm{C}$, whereas blends of PLA and plastic (Epoxidized Palm Olein) decreased the melting point [15]. DSC studies from a PLA plastic glass showed melting points between $142-145^{\circ} \mathrm{C}$ depending on the top or the bottom of the glass, showing the glass had similar melting points but different glass transition temperatures and crystallinity [22].

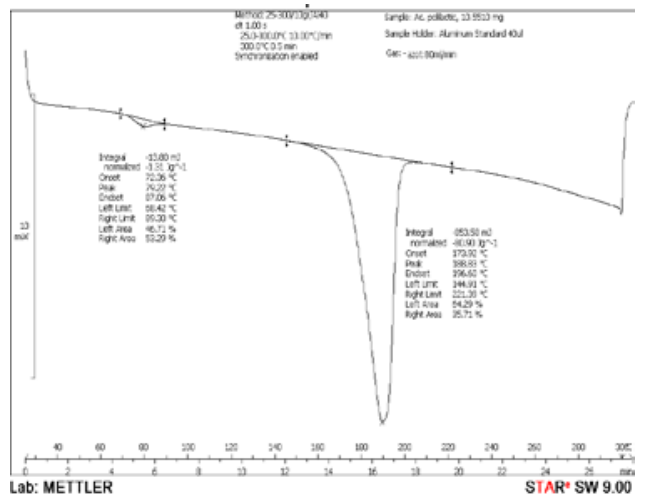

a

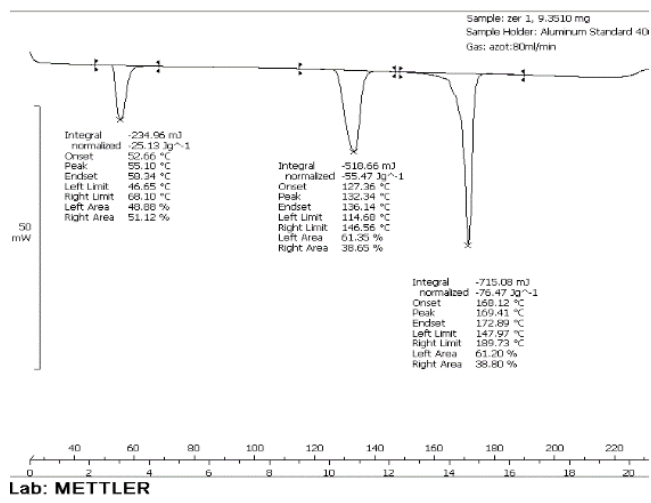

b

Figure 2. Assessments of commercial PLLA (a) and experimental PLLA(b) physical property (melting point) through DSC method.

\section{Sterility test}

Both products have been diluted/washed in a sterile broth solution. The standard polymer used for the determination has not dissolved in contact with the nutrient broth, while the synthesis polylactic polymer has dissolved in contact with the nutrient broth. For the standard polymer we consider the TOTAL GERM COUNT evaluation of the surface due to maintaining solid form in contact with the sterile broth and for the synthesis polylactic polymer we consider the TOTAL GERM COUNT for the whole product due to dissolution in the sterile broth. No colonies were found on the surface or in the depth of the agar at 24,48 or 72 hours. Both samples were sterile: Total Germ Count $=0\left(\mathrm{cfu} / 10^{-1}=0\right)$. The use of ultraviolet radiation for 24 hours, in the case of the tested products, was appropriate considering the load of germs. The polymers tested may be used in biological contexts without imposing contamination danger. Although gamma radiation is the preferred method for medical devices sterilization [23], the method of sterilization by ultraviolet radiation for 24 hours was favorable, respecting hygiene rules in the course of the manufacture and handling. 


\section{Cell viability}

The mitochondrial dehydrogenase performance measurement is a rapid assessment of cell proliferation and cytotoxicity [17]. The MTT assay is currently the most used method to test cytocompatibility of medical devices. Our study revealed that both, experimental and commercial polymer showed a good cytocompatibility (Fig. 3, Fig. 4). Only control cells treated with DMSO showed a decrease in viability (51.89\%) in comparison with the control and all the other concentrations. The cells viability treated with extract from the commercial polymer showed a slight decrease at the concentration of 20 $\mathrm{mg} / \mathrm{ml}(82 \%)(p<0.01)$ in comparison to the control. However, this decrease was not under $80 \%$, showing thus a good cytocompatibility (Fig. 3). The percentage of cellular viability was above $89 \%$ for all the tested extract concentrations from the experimental polymer. Moreover, cells treated with concentrations of $20 \mathrm{mg} / \mathrm{ml}, 10 \mathrm{mg} / \mathrm{ml}, 5 \mathrm{mg} / \mathrm{ml}$ and respectively $1.25 \mathrm{mg} / \mathrm{ml}$ showed an increase in cell viability, exceeding 100\%, indicating that these concentrations promoted cell proliferation (Fig. 4). Additionally, the low cytotoxicity of the experimental PLA was demonstrated by calculating the IC 50 of the extract (Fig. 5). It showed that a concentration of $64.82 \mathrm{mg} / \mathrm{ml}$ or a higher concentration could reduce the number of viable cells at half. The results of the research were comparable to a previous study, in which it was reported that PLA scaffolds were biocompatible at 24, 48 and 96 hours [16], demonstrated by MTT test and also by direct contact test, showing cell adhesion and migration on the scaffold. Similar results to our study were reported by Vergnol et al, 2015 as well [24]. Good biocompatibility of PLA composites was demonstrated using Presto Blue assay at 6 and 10 days after incubation, although the authors stated that cell viability decreased with the increase of the concentration of the extract [24]. Even PLA nanoparticle formulations were found to be non-toxic in the concentrations studied. Cell viabillity was between $80 \%$ and $120 \%$ after treatment with different concentrations of PLA nanoparticles extract [18]. The MTT test was declared a useful method for measuring the subtle toxicity of biomaterials, regarding cell metabolism and functions, even if cells do not die in 24-72 hours, the usual time for a cytotoxicity test. Biomaterials display different rates of toxicity, being cytostatic, affecting a cell function or damaging a whole cell compartment [25]. The results of the current study have proved that the cytotoxicity level of PLA can be determined by the period of time in which the polymers extract acts on the cell culture. In addition, the cellular viability can be affected by the method used to obtain PLA and by the compounds used in the lactic acid extraction process [24]. When aqueous extracts of the biomaterials are used, they seem 
to provide suitable samples of potentially hazardous substances that may leach out from a device [26]. According to the previous statement, the synthesis method used to create the polylactic polymer from ZONAR is safe and reliable. Also, according to our data both polymers, commercial and experimental, showed no toxicity, the cellular viability being unaffected.

Wi-38 Comercial PLA

$48 \mathrm{~h}$

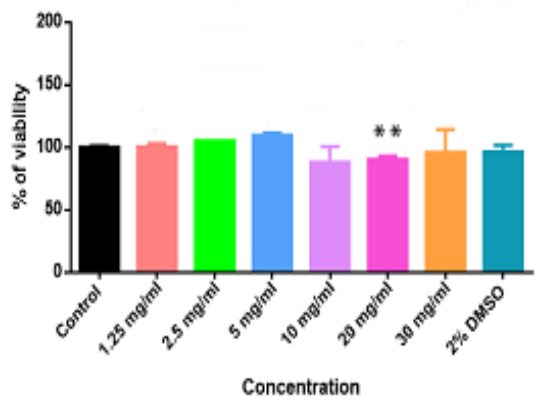

Figure 3. Cytotoxicity assessment of commercial PLA extract using MTT assay on fibroblasts cells at 48 hours, ${ }^{* *} \mathrm{p} \leq 0.01$.

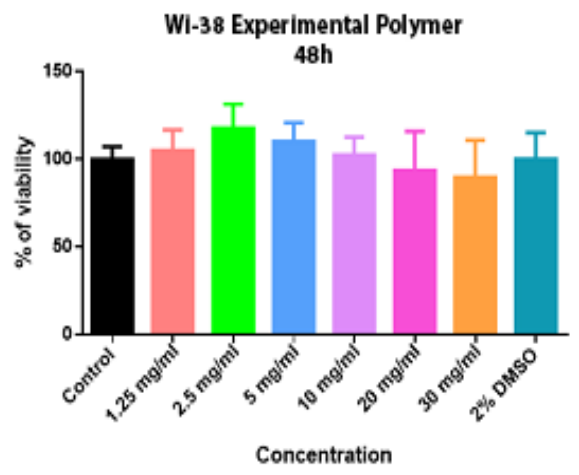

Figure 4. Cytotoxicity assessment of experimental PLA extract using MTT assav on fibroblasts cells at 48 hours.

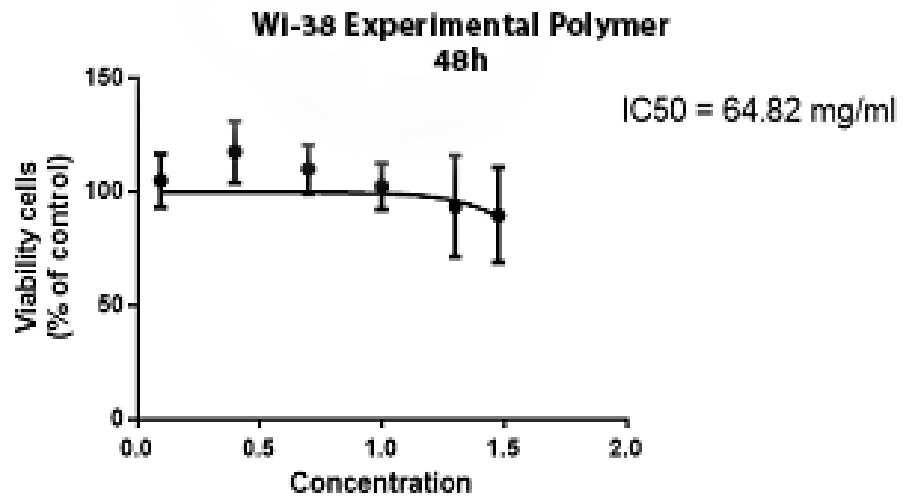

Figure 5. Assessment of the IC 50 on viability of fibroblasts cells after treatment with PLA extract at 48 hours. 


\section{CONCLUSIONS}

Extracting lactic acid from whey (ZONAR) and converting it into PLA represents an innovative \& promising technology, providing biomaterials for many economical fields. The poly- $L$ lactic polymer synthesis from the whey Zonar is a reliable \& eco-friendly process, able to provide a low molecular polymer fulfilling 3 essential features, such as nontoxicity, renewability and high biocompatibility.

\section{EXPERIMENTAL SECTION}

\section{Samples synthesis}

For Synthesis of lactic acid by fermentation, we used whey (Zonar SC Embrion, Satu Mare, Romania), molasses (Tereos Romania, Ludus), and Ecoflorina (Lactobacillus bulgaricus) to $\mathrm{pH}=5,0-6,0$, temperature $44-45^{\circ} \mathrm{C}$ and the lactic acid polymerization, was done by polycondensation.

Commercial PLA A commercial PLLA was purchased from Sigma Aldrich, with the following characteristics: Lot: BCBP2966V, 81273-10G, molecular weight: 260 000, viscosity: $2.0 \mathrm{dl} / \mathrm{g}$.

\section{Material characterization}

\section{Scanning electron microscopy}

The experimental PLA obtained was characterized by: Scanning Electron Microscopy (SEM-Inspect S, FEI Company), with an acceleration voltage of $15 \mathrm{kV}$ in order to observe the biomaterials surface.

\section{DSC analysis}

A differential scanning calorimetry (DSC) analysis using a Mettler Toledo DSC $823 \mathrm{e} / 700{ }^{\circ} \mathrm{C}$ was performed, in order to obtain the melting point of the biomaterial.

\section{Sterility test}

Samples of the experimental and standard polymer were placed in glass recipients and sterilized through UV light, for 24 hours. A microbiological test was performed in order to assess the sterilization capacity of UV light. The method used was the indirect method for the evaluation of the total germ number (ufc) on solid medium for mesophilic germs. It was considered that each colony on the surface of the testing medium was the result of the multiplication of one bacteria [27]. Both products have been included in $0.1 \mathrm{ml}$ 
sterile nutrient broth. The solution was subsequently passed in the Petri dishes with the Muller Hinton agar by flooding method. The samples were incubated at $37^{\circ} \mathrm{C}$ and then evaluated at 24,48 and 72 hours.

Cell viability - The in vitro test for cytotoxicity was performed according to International Organization for Standardization (ISO) - ISO 10993-5" Test for in Vitro Cytotoxicity [28].

Polymer extract. The extracts for the experimental and commercial polymer regarding the cytotoxicity test was performed according to ISO 10 993-12 "Sample Preparation and Reference materials" [29].

Cell culture For the experiment were used human fibroblast cell line, Wi38. Wi-38 cell line was cultured in Gibco® MEM Medium, supplemented with $10 \%$ Fetal bovine serum (FBS - Gibco®), 2 mM L-glutamine (Gibco®), MEMNEAA (MEM Non-Essential Amino Acids Solution (100X) - Gibco®) and 1\% Penicillin-Streptomycin. Cells were incubated in a $5 \% \mathrm{CO}_{2}$ incubator at $37^{\circ} \mathrm{C}$.

MTT assay Cell survival was assessed using MTT assay. Adherent cells were cultivated at sub confluence before being washed twice with phosphate-buffered saline (PBS 1X). After trypsinization, cells were resuspended in culture medium with FBS 10\%, counted and seeded for the experiments. A number of $10^{4}$ cells were seeded in 96-well plate and incubated for 24 hours. After incubation, cells were treated with the experimental polymer obtained through synthesis and with the extract from the commercial PLA, using six solutions of different concentrations, respectively $30 \mathrm{mg} / \mathrm{ml}, 20 \mathrm{mg} / \mathrm{ml}, 10 \mathrm{mg} / \mathrm{ml}$, $5 \mathrm{mg} / \mathrm{ml}, 2.5 \mathrm{mg} / \mathrm{ml}$ and $1.25 \mathrm{mg} / \mathrm{ml}$. The cell viability was related to the negative control wells. DMSO was used for positive cytotoxic control. For each concentration of the extract, the test was performed in triplicate. The proliferation activity of the cells was evaluated after 48 hours using MTT (Thiazolyl Blue Tetrazolium Bromide, Sigma-Aldrich, Germany) test. Cells were incubated for 3 hours with $150 \mu \mathrm{l}$ MTT and the metabolized formazan salt was resolubilized in $100 \mu \mathrm{l}$ DMSO, incubated for 10 minutes on a shaker. Afterwards, we read the absorbance at $570 \mathrm{~nm}$ with a multi-plate spectrophotometer BioTek Synergy.

\section{Statistical analysis}

All data is reported as mean \pm SD from the experiment performed on triplicate samples. The differences between experimental conditions and controls were analyzed using $T$ test. Statistical significance was at $p<0.05$ (95\% confidence interval). Statistical values and figures were obtained using GraphPad Prism version 6.0 for Windows, GraphPad Software, San Diego California USA. Cell viability was determined as a percentage of the negative control (untreated cells). 
A. DREANCĂ, R. A POPESCU, A. NEAGU, G. ENACRACHI, I. CIMPOEȘ, N. FIȚ, M. MOLDOVAN, ...

\section{ACKNOWLEDGMENTS}

This work was supported by a grant of the Romanian National Authority for Scientific Research and Innovation, "CNCS/CCCDI - UEFISCDI, project number PN-III-P2-2.1-BG-2016-0335, within PNCDI III". The authors wish to thank associate professor doctor Lucian Baia and CSIII Klara Magyari from the Institute on Bio-Nano-Sciences for providing commercial polylactic acid and advice in terms of physical characterisation.

\section{REFERENCES}

1. P.M.R. Guimarães, J.A. Teixeira, L. Domingues, Biotechnology Advances, 2010, 28, 375.

2. www.wheyeurope.com

3. C. Spalatelu, Innovative Romanian Food Biotechnology, 2012, 10, 1-8.

4. P.S. Panesar, J.F. Kennedy, D.N. Gandhi, K. Bunko, Food Chemistry, 2007, 105, 1.

5. S. Maslanka, M. Siolek, L. Hamryszak, D. Lopot, Chemik, 2014, 68(8), 703.

6. S. Maslanka, A. Kos, M. Bankzyk, I. Kzopek, L. Adam, Chemik, 2015, 69(4), 241.

7. L. Xiao, B. Wang, G. Yang, M. Guthier, Biomedical Science, Engineering and Technology, 2012, 11, 248.

8. R.E. Drumright, P.R. Gruber, D.E. Henton, Advanced materials, 2000, 12(23), 1841.

9. S.M. Davachi, B. Kaffashi, Polymer-Plastics Technology and Engineering, 2015, 54(9), 944.

10. M.S. Lopez, A.L. Jardini, R. Maciel Filho, Procedia Engineering, 2012, 42, 1402.

11. A.J.R. Lasprilla, G.A.R. Martinez, B.H. Lunelli, J.E.J. Figueroa, A.L. Jardini, R. M. Filho, Chemical Engineering, 2011.

12. L.T. Lima, R. Auras, M. Rubino, Progres in Polymer Science, 2008, 33, 820.

13. D. Garlotta, Journal of Polymers and the Environment, 2001, 9(2), 63.

14. S. Farah, D.G. Anderson, R. Langer, Advanced Drug Delivery Reviews, 2016, 2.

15. V.S. Giita Silverajah, A.I. Nor, Z. Norhazlin, Y. Wan Md Zin Wan, A.H. Hazimah, Molecules, 2012, 17, 11729.

16. S. Shi, X.H. Wang, M. Fan, M.J. Huang, Z.Y. Qian, International Journal of Nanomedicine, 2010, 5, 1049.

17. S. Zhou, X. Deng, X. Li, W. Jia, L. Liu, Journal of Applied Polymer Science, 2004, 91, 1848.

18. A. Basarkar, D. Devineni, R. Palaniappan, J. Singh, International Journal of Pharmaceutics, 2007, 343, 247.

19. R. Auras, B. Harte, S. Selke, Macromolecular Bioscience, 2004, 4, 835. 
20. T.M. Quynh, H. Mitomo, M. Yoneyama, N.Q. Hien, Polymer Engineering and Science, 2009, 49(5), 970.

21. J. Palacio, V.H. Orozoco, B.L. Lopez, Journal of Brazilian Chemical Society, 2011, 22(12), 2304.

22. www.tainstruments.com

23. M. Silindir, A.Y.Ozer, Fabad Journal of Pharmaceutical Sciences, 2009, 34, 43.

24. G. Vergnol, N. Ginsac, P. Rivory, S. Meille, J.M. Chenal, S. Balvay, J. Chevalier, D.J. Hartmann, Journal of Biomedical Materials Research Part B, 2015, 00B:000-000.

25. G. Ciapetti, E. Cenni, L. Pratelli, A. Pizzoferrato, Biomaterials, 1993, 14(5), 359.

26. L.S. Desai, L. Lister, Toxikon Advancing your innovation, 1-19 www.toxikon.com

27. USP $40,61,1-7$

28. International Organization for Standardization, ISO 10993-5, 2009, 1-34.

29. International Organization for Standardization, ISO 10993-12, 2004, 1-20. 
